\title{
Study of the Space Form Changes of Guanzhong Rural Houses in One Hundred Years Under the Production
}

\author{
Wang Xiaojing, Yang Dan \\ College of Architecture, School of Architecture Xi'an University of Architecture \& Technology, Xi'an, China \\ Email address: \\ 626110330@qq.com (Wang Xiaojing), 452634045@qq.com (Yang Dan) \\ To cite this article: \\ Wang Xiaojing, Yang Dan. Study of the Space Form Changes of Guanzhong Rural Houses in One Hundred Years Under the Production. \\ Science Research. Vol. 5, No. 2, 2017, pp. 10-15. doi: 10.11648/j.sr.20170502.11
}

Received: April 11, 2017; Accepted: May 5, 2017; Published: May 10, 2017

\begin{abstract}
To improve the inefficiency and enclosure space of Guanzhong rural houses, this paper in the perspective of rural first vitality "production", focuses on Xuelu village in Qianxian to explore the influence mechanism of rural production and the house space form. The study relying on methods such as literature research, field investigation, summary, selecting 100 years with rural drastic changes from the Republic of China to current stage (1912-2016), analyzes the inheritance and transformation of rural production, the housing construction, the production space of buildings, courtyards and the transition space, and aims to put forward some reasonable guidance for the construction of rural houses in Guanzhong.
\end{abstract}

Keywords: Production, Guanzhong Rural House, Space Form, Changes of One Hundred Years

\section{Introduction}

Rural settlements are the gathering place of production and life. Production is the foundation of the rural economy and development, which constructs the social order, life picture and the layout of villages. There have been a large number of researches on rural production and space in China. Wang Yong [1] studied the transformation of rural space in South of Jiangsu by space production, showed the rural transformation was divided into rural autonomy, market driven and government led three stages, and the content of production space changed from the "industrial production of space" to "living space". Xi Jianchao [2] adopted PRA and GIS technology in Gou Ge Zhuang village as the case, a typical tourism village, analyzed tourism rural settlements' spatial pattern evolution of "production, life and ecology" in the past thirty years. Ye Litian [3] analyzed the form change of rural settlements in Chengdu plain by production and put forward the corresponding design strategy. However, it relatively lacks studies on the space form of the rural house, the constituent cell of a village. Therefore, this paper takes rural houses in Guanzhong area as the research object, discusses the evolution mechanism of space form caused by production, and induces the heritage in transition to make some reasonable guidance for the current construction of rural houses.

\section{Methodology}

\subsection{Selecting the History Span and Slice}

Considering the data desirability and the change integrity, this paper selects 100 years with rural drastic changes from the Republic of China to current stage (1912-2016). With the rural economy changes as the clue, the 100 years are divided into five stages, namely the Republic of China period (1912-1949), the agricultural cooperative period (1950-1958), the people's commune period (1959-1983), the initial stage of reform and opening-up (1984-2001) and the present stage (2002-2016) (Fig.1). And then one specific year is chosen from each stage to obtain data, such as the Republic of China period for 1935, the agricultural cooperative period for 1954, the people's commune period for 1971 , the initial stage of reform and opening-up for 1985 and 1998, the present stage for 2015.

\subsection{Selecting the Field Object}

Xuelu village in Qianxian is selected as the field investigation object, an administrative village with the government seat. Since ancient times the production changes of Xuelu is ordinary and common with no special resources, representing majority of rural settlements in Guanzhong. Select three typical households, LJX family (ordinary 
villagers, born in people's commune period, engaged in agricultural and sideline), LTM family (village accountant, born in agricultural cooperative period, engaged in agricultural and sideline) and LXR family (ordinary villagers, born in Republic of China period, engaged in sideline business) to interview and restore production content, house construction, production function, layout and usage of house from the (great-)grandparents generation in the Republic of China to the (grand)children generation living in present stage. Fig. 2 shows LJX family how to use the house space when having a wheat harvest in 2015.

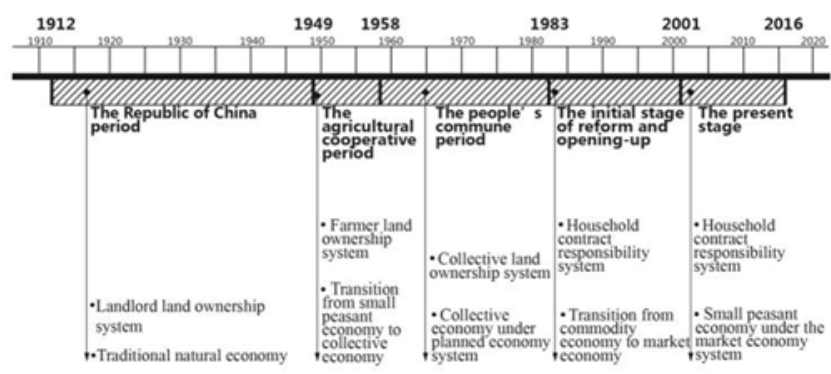

Figure 1. Centennial changes of rural economy in China.

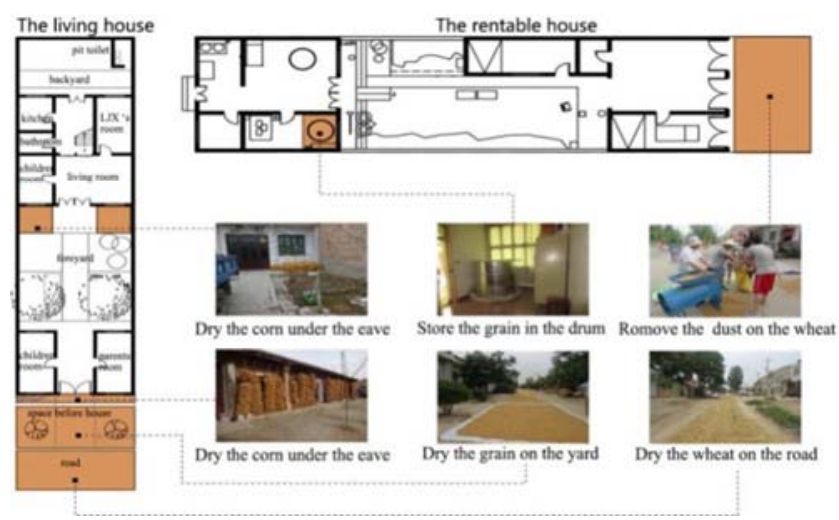

Figure 2. Some agricultural production activities and space of houses of LJX family in 2015.

\section{Production Changes of Xuelu Village in Recent 100 Years}

According to the characteristics of rural economic development, the production of Xuelu village in recent 100 years is divided into four stages: the Republic of China, the agricultural co-operative period (1912-1958), the people's commune period (1959-1983), the initial stage of reform and opening-up (1984-2001) and the present stage (2002-2016).

\subsection{Agricultural Production}

\subsubsection{Production Materials and Objects}

During the Republic of China and the agricultural co-operative period, with social unrest rural mode of production was traditional farming production. The productivity was too backward that vast land yielded few of grains for lacking water. Production materials mainly contained plows, hoes, shovels, farmyard manure and other traditional hand tools. However, the poor family with insufficient materials usually had to borrow large tools as stone mills, donkey carts from the landlord in the way of "labors exchanged tools". What's more, the farmlands were divided in small and far away from home. Villager LXR recalled his family owned 16 acres of land, of which 6 acres was 6 miles distant from the village, thus he often worked at sunrise and retired at sunset during that time. The crops were wheat, corn, millet, etc..

In the people's commune period, rural collective works were arranged by the production team and all production materials were collectively owned under the planned economy system. Villagers leveled the field, built irrigation works - the Qianxian County section of Baoji gorge project, and provided supplements of traditional farming tools, chemical fertilizers, tractors. The crops were cotton, wheat, corn, etc.

In 1982 the household contract responsibility system was carried out throughout the country, hence the production mode in the family was restored. As the number and quality of farming tools had been greatly improved, tractors and agricultural vehicles were in common. Implying the fixing of farm output quotas for individual households with each on its own, LXR family was shared 7 acres of land. The crops were wheat and corn. Fruit trees and other economic crops were introduced in the late 1990s.

At this stage with the transformation from traditional agriculture to modern agriculture, traditional farming tools turned to machine tools, such as harvesters, plowing machines, pumps. The phenomenon of land transfer is popular. Economic crops proportion of Xuelu village is higher than grain crops, which made Xuelu become a peach and apple village.

\subsubsection{Laborers and Production Relations}

During the Republic of China and the co-operative period, male farming and female weaving is the most common labor-division pattern of rural family. In the years when productivity was backward, individuals were so insignificant that the family relied strongly on relatives, neighbors. Villagers helped each other to form a highly homogeneous village community with the strong sense of collective consciousness and identity.

In the people's commune period, everyone labored. Men and women, the old and young were arranged different tasks in accordance with the physical capacity and then given work points according to the work standards. The collective labor of production team made production and life synchronization.

At the initial stage of reform and opening-up, young men and women were the main force in the household production. During the busy farming season the old and children involved in family works, and meanwhile different families would take turns to make production with mutual assistance. The production team unified the usage of large agricultural tools.

At this present stage, the old and women left behind have become the main labor force. With the intervention of the market economy, the improvement of productivity and the reduction of production scale, the family dependency on rural collective is declining greatly which makes the relationship of 
neighborhood weaker and weaker.

\subsubsection{Input and Output}

During the Republic of China and the co-operative period, villagers spent most of a year and energy into production, but the grain output was still not enough to satisfy the body's energy needs. In 1935, LXR family had 8 people and a harvest about 1243 kilograms of grain. The grain deduced $41 \%$ exorbitant tax, left only $0.25 \mathrm{~kg}$. per capita daily. From 1928 to 1931, Guanzhong encountered catastrophic drought, caused most areas reaped nothing.

During the commune period, villages carried out the collective management. LTM recalled that all laborers got up at four or five in the morning and went back home to rest at eight or nine in the evening. The imbalance between labor input and output seriously eroded the incentive and enthusiasm of production. During the three-year difficult period (1959-1961), villagers only had $0.3 \mathrm{~kg}$. of grain per capita daily. At the beginning of 1970 s, the annual income per head was only about 40 yuan, until in the end of 1970s the income increased to 70 yuan. Immediately after that, housing consumption grew up.

At the initial stage of reform and opening-up, the production was still the traditional mode, but the output could basically satisfy family food with advanced production materials. In 1990s the grain yield was up to $1-1.6 \mathrm{~kg}$. per capita daily.

Currently, the mechanization of agricultural production has promoted the reduction of production cycle. The time of harvesting wheat in the past more than one month now has been cut down to only a few days. With the increasing free time and energy released, villagers have to doze their days away by watching TV and other economical behavior. In addition, the ecnomic crops become the main source of agricultural income. In 2015, LJX family planted 3.2 acres of wheat and corn, 2.5 acres of apple trees and earned 15 thousand yuan for food crops but 45 thousand yuan for apples.

\subsection{Sideline Production}

\subsubsection{Production Content}

During the Republic of China and the co-operative period, female made spun and wove cloth, raised poultry, while men did casual labors or business in exchange for the basic living materials.
During the Commune period, individual sideline was prohibited. However, due to the shortage of materials, the villagers still engaged in speculation. LXR's wife said in that years she and her companions often sneaked into factories at midnight in Xingping to sell eggs for subsidizing home. Meanwhile, production teams were popular to run workshops or factories, such as farms, brickyards etc..

During the initial period of reform and opening-up, rural free trade was admitted so that setting up factories and doing work for others flourished. In slack seasons, the scope of operated the subsidiary business expanded to provincial capitals or other provinces. LXR's son left the province to work in the South. LTM worked on a building site in Xi'an. LJX sold scrap iron with his father in Xuelu village.

At the present stage, the low income of agricultural production makes villagers devote more to sideline production. As the fading of rural enterprises leads to majority of villagers leaving for work, rural production is separated with rural life. What's more, rental transactions of rural houses are emerging which is forbidden by the law.

\subsubsection{Input and Output}

In the Republic of China and the cooperative period, village women would spend their whole lives to spin and weave cloth. Usually in one year a woman could obtain 200 to $300 \mathrm{~kg}$. of grain by changing her cloth, while a man working for the load just got about 150 to $250 \mathrm{~kg}$. of grain.

During the commune period, the sideline income of a family was decided by the number of laborers. All laborers' work points were converted into grain or money.

During the initial period of reform and opening-up, LJX could earn 800 yuan a month by selling scrap; LTM could earn 230 yuan a month in buiding-construction. There were no doubts that agricultural production had solved the problem of food and clothing and sideline production was improving rural living. Naturally, it was inevitable that the house construction bloomed rapidly.

At this stage, the house rent becomes a new form of rural sideline production. LJX can get rents of 20000 yuan per year for two houses. LXR's second son also obtains a year income of 2000 yuan for one rental house. With the traditional habit of favoring the house construction and ceremony ostentation, the income of a rural family is mainly used for the consumption of housing, marriage and funeral.

\section{House's Space Form Changes of Xuelu Village in Recent 100 Years}

\subsection{Building Houses Induced by Economic Development}

Table 1. The index changes of housing construction of Xuelu village in one hundred years

\begin{tabular}{|c|c|c|c|c|}
\hline Context & $\begin{array}{l}\text { The Republic of China and } \\
\text { cooperative period }(1912-1958)\end{array}$ & $\begin{array}{l}\text { The people's commune } \\
\text { period }(1959-1983)\end{array}$ & $\begin{array}{l}\text { The initial stage of reform and } \\
\text { opening-up (1984-2001) }\end{array}$ & $\begin{array}{l}\text { The present stage } \\
(2002-2015)\end{array}$ \\
\hline Construction stage & Slow construction & The first update:extension & The second update:newly build & $\begin{array}{l}\text { The third } \\
\text { update:newly build }\end{array}$ \\
\hline Homestead size & $4 m-6 m \times 20 m-60 m$ & $6 \mathrm{~m} \times 30 \mathrm{~m}$ & $9 \mathrm{~m} \times 30 \mathrm{~m}$ & $9 \mathrm{~m} \times 33.5 \mathrm{~m}$ \\
\hline Total building area & $80.1 \mathrm{~m}^{2}$ & $127.2 \mathrm{~m}^{2}$ & $286 \mathrm{~m}^{2}$ & $615 \mathrm{~m}^{2}$ \\
\hline Building area per household & $34.2 \mathrm{~m}^{2}$ & $46 \mathrm{~m}^{2}$ & $73.7 \mathrm{~m}^{2}$ & $159 \mathrm{~m}^{2}$ \\
\hline Building area per head & $10.5 \mathrm{~m}^{2}$ & $12.9 \mathrm{~m}^{2}$ & $29.2 \mathrm{~m}^{2}$ & $76 \mathrm{~m}^{2}$ \\
\hline
\end{tabular}


Induced by the development of rural economy, houses construction has changed three times: the number and function of houses changes from none to presence, from less to more, from more to empty (Tal.1). That's all the villagers' pursuit of house scale corresponds with their production and living needs.

In the Republic of China and the cooperative period, the house was made by mud, including a gatehouse and a single wing room. There was scarcely a central room in poor family (Fig.3). The number of rooms was few but the function of rooms was highly complex. During the people's commune, houses of Xuelu village experienced the first renovation and was added a kitchen and a children's room. In the initial stage of reform and opening-up, houses updated for the second time. Villagers applied for new homesteads to build new houses made by bricks and concrete, which still remained the traditional space form consisted of gatehouses, wing rooms and central rooms. The new house contained parents room, children room, kitchen, living room and granary. At this stage, houses updated for the third time. Villagers applied for more homesteads for their getting-married sons. The house mostly is a building of 2 storeys with more detail function, which adds a bathroom and cancels the gatehouse or wing rooms.

\subsection{The Exclusive and Shrink of Production Room}

Process and storage is the important content of the rural production. The process and storage space of houses shows the transition from the highly function integration to the function withered and then the space vacancy (Fig. 4).

During the Republic of China and the cooperative period, the living space overlapped the production space. Especially, the parents room was the complex of the kitchen, products process and food storage. During the people's commune, the kitchen separated from the parent room, becoming another core production space. At the initial stage of reform and opening-up, the separated granary and central room shared production with kitchen. The central room had become the main agricultural processing and storage space in a house. At the present stage, withered production activities lead to the shrinking production space. There have no formal processing space in a house, but a large number of vacant rooms for storage. Meanwhile, as the rural production is less and more convenient, certain exclusive production rooms are abandoned and replaced by the compound space. For a case, villagers nowadays are accustomed to store grains into the kitchen but not the granary.

\subsection{The Shrink of Courtyard Production}

Courtyards including the space before house, the foreyard, the site yard and the backyard, are the main place of family production. The production activities change with the location of yards and the evolution of production structure. That is to say the production in the foreyard is more public than the backyard and the production is transforming from economic attributes to ecological attributes (Fig.5).
In the Republic of China and the cooperative period, courtyards were used for drying grain, processing products, storage of agricultural materials. What's more, the backyard was strongly private to raise livestock. In the commune period, there was no household production in rural houses. In the initial days of reform and opening-up, the conventional courtyard production was restored. At present, the production is reduced. There is no raising livestock or the occasional drying food and more planting vegetables, flowers and trees in yards.

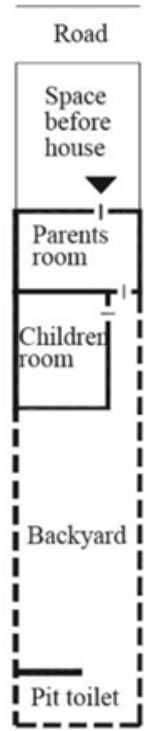

(a) the Republic of China and the cooperative period

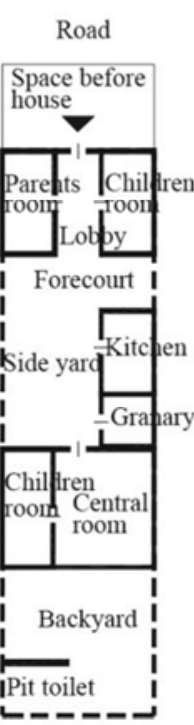

(c) the early stage of reform and opening-up

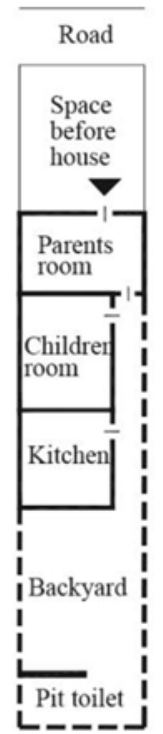

(b) the people's commune period

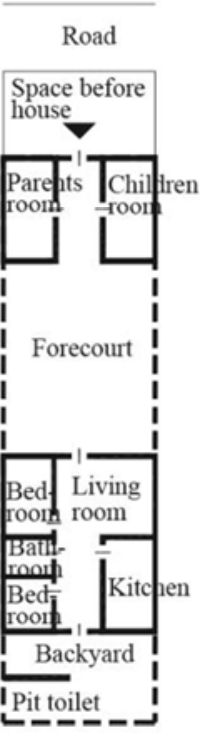

(d) the present stage
Figure 3. Typical house plan changes of Xuelu village in one hundred years. 


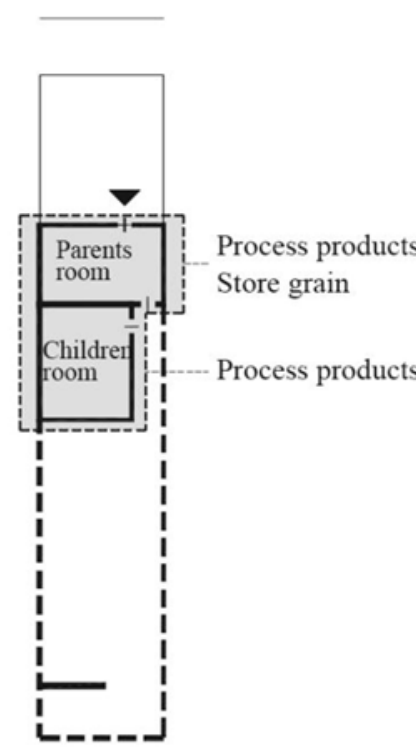

(a) the Republic of China and the cooperative period

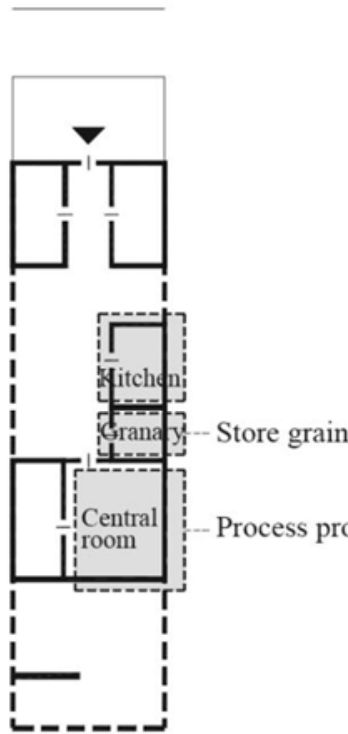

(c) the early stage of reform and opening-up

Figure 4. Production room changes of typical house of Xuelu village in one hundred years.

\subsection{The Invariable Property of Transitional Space}

Transition space connects individuals, families and neighborhoods, as well as artificial and natural environment, where is not the exclusive production space in a house but with the high frequency of production activities. Transitional space includes eaves, porches, lobbies and the production is effected by its location (Fig.6). From the Republic of China to the present stage, because of the strong publicity of transitional space production, it is where more activities take place than other places all the time. The production in transition space of gatehouse is shared, while of wing room is household, of central room is private.

\section{Conclusions and Suggestions}

As the starting point of rural society development, rural production constructs rural life and culture different from that of cities. The production output is the economic base for villagers to build houses and the production content is the main factor affecting the house space. From 1912 to 2016, about one hundred years, the living conditions of rural houses changes from narrow and crowded to spacious and vacant; the household production changes from heavy and inefficient to reduced and then disappearing; the production space changes from few and complexed to exclusive then to empty and complexed once again.

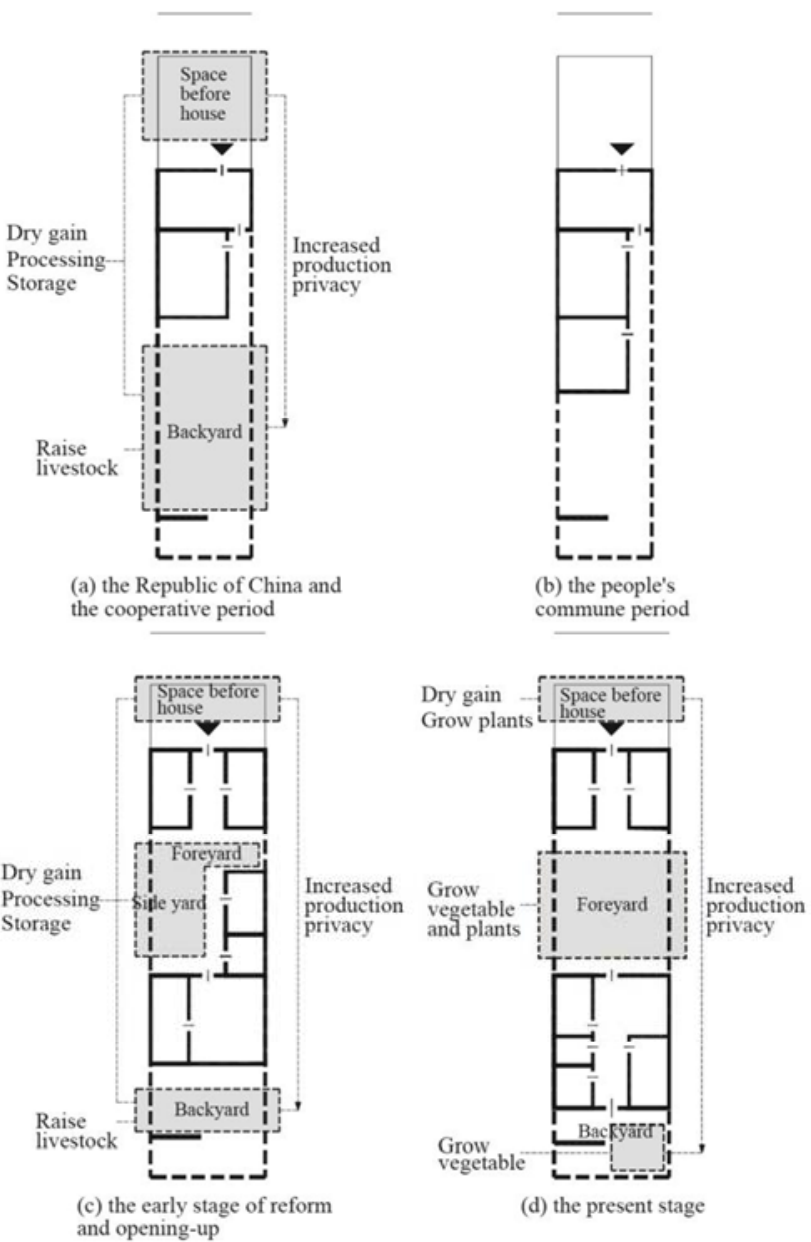

Figure 5. Courtyard production changes of typical house of Xuelu village in one hundred years.

Faced with the problem of current rural houses space form, there is no time to optimize the space form as well as the rural production. Firstly, revive rural enterprises and household handicraft industry to bring into the new content of rural production. Secondly, encourage non-collective members to settle in villages and promote the diversification of residential patterns to digest house vacancy. Thirdly, change and enrich the closed space form of buildings, courtyards and transitional space. Last but not least, transform the production space to living space and landscape space to recreate the rural life. 


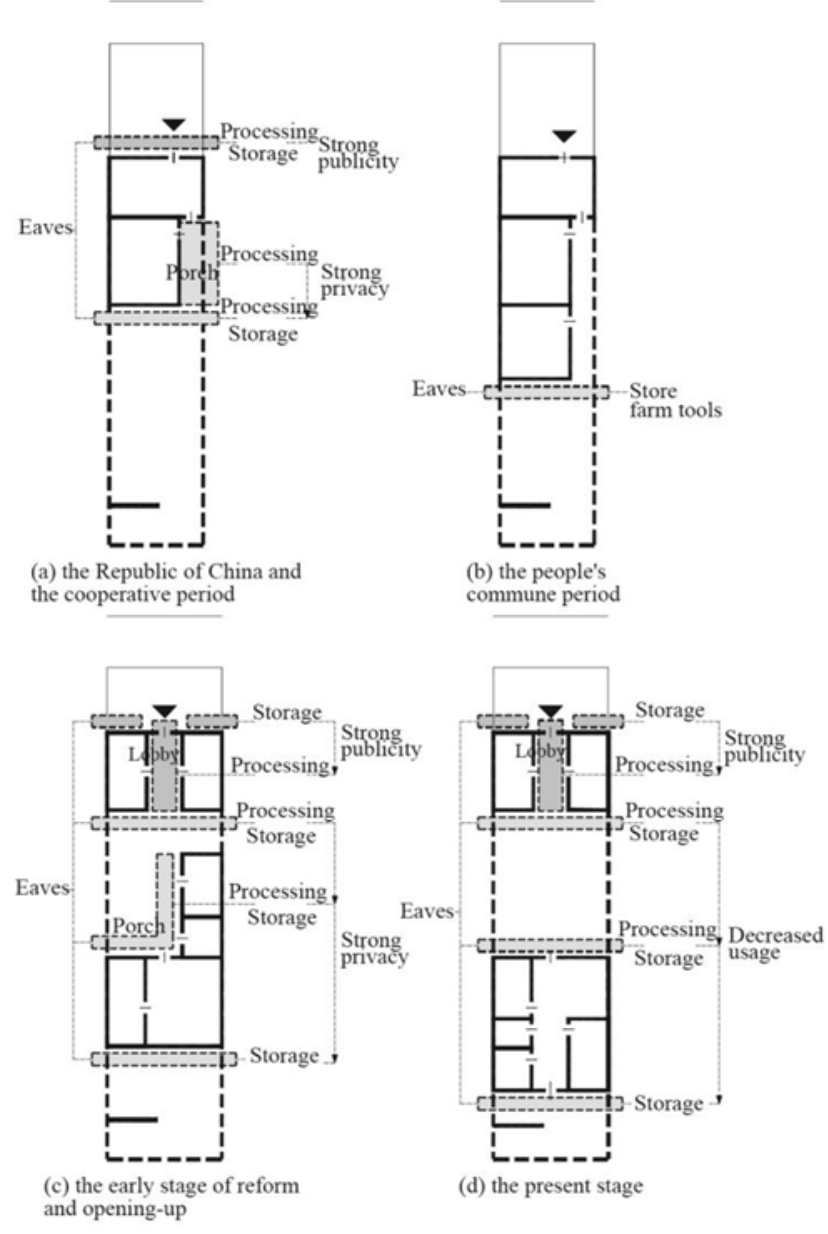

Figure 6. Transitional space production changes of typical house of Xuelu village in one hundred years.

\section{References}

[1] WANG Yong, LI Guangbin, WANG Chuanhai. South of Jiangsu rural space transformation and planning strategy based on space production [J]. Planners, 2012(04):110-114.

[2] XI Jianchao, WANG Shoukun, ZHANG Ruiying. The reconstruction and optimization of the "production, life and ecology" of tourism rural settlements -- a case study of Sanyepo village, Hebei $[\mathrm{J}]$. Journal of natural resources, 2016(03):423-435.

[3] YE Litian. A study of the influence of the production mode on rural settlements in the urban and rural development -- a case of Chengdu plain [D]. Master's degree thesis of Southwest Jiao Tong University, 2013.

[4] LI Li. Rural Settlements: Form,Type and Evolution - a Case of Jiangnan Region [M]. Nanjing: Southeast University Press, 2007.

[5] LI Bin, CHEN Chen. A study on the house form and usage of natural village -- a case of $\mathrm{J}$ village in Shanghai [J], Architectural Journal, 2011(S2):116-120.

[6] YANG Dan. Study of the space form changes of Guanzhong rural houses in One Hundred Years under the land system [D]. Master's degree thesis of Xi'an University Of Architecture And Technology, 2016.

[7] Editorial Committee of the Qianxian County. Journal of Qianxian County [M]. Shaanxi people's publishing house, 2003.

[8] LUO Hongyun. Study of rural land system in China (1949 2008) $[M]$. Shanghai: Shanghai University of Finance and Economics press, 2012.

[9] WANG Xiaojing, YANG Dan. Study of the space form changes of Guanzhong rural settlements in one hundred years under the life - a case analysis of Xuelu village in Qianxian [J]. Urbanism and architecture, 2017(04).

[10] WANG Xiaojing, YANG Dan. Study of spatial texture changes of Guanzhong rural settlements in one hundred years by the homestead system [J]. Architecture and culture, 2017(05). 